\title{
An Urgency for Extraordinary Member to Take Tests to Fulfil the Requirements to be Notary Public Official
}

\author{
Dessy Agustina Harahap ${ }^{1}$, Windy Sri Wahyuni ${ }^{2}$ \\ ${ }^{1,2}$ Faculty of Law, Universitas Medan Area, Medan, Indonesia \\ Dessyagustina86@yahoo.com
}

\begin{abstract}
This research deals with an urgency for extraordinary member to take tests to fulfil the requirements to be notary public official. This type of research used in this study is normative legal research. The results shows that The extraordinary Members
\end{abstract}

Keywords

extraordinary member, test; notary

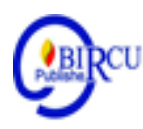

\section{Introduction}

Notary is a public official authorized to make an authentic deed, as long as the making of the authentic deed is not specific to other public officials. A public notary as a public official is a person who carries out part of the public functions of the State, especially in the field of civil law. The making of authentic deeds is required by statutory regulations in order to create certainty, order and legal protection.

Such is the importance of the role of a Notary given by the State, where the Notary Public is demanded to be responsible for the deed he made. A Notary must comply with applicable regulations, namely the Law of Notary Position and obey the code of ethics of the legal profession, namely the Notary code of ethics. If the deed that was made turned out to be behind the day contained a dispute then this needs to be questioned, whether this deed was a deliberate notary mistake to benefit one of the parties to the party or the mistakes of the parties who did not provide the actual documents. If the notary deed made / issued contains legal defects due to notary errors either due to negligence or due to the intentional notary itself, the notary must provide accountability morally and legally, and of course this must first be proven.

The requirements to be appointed as a notary are:

1. Indonesian Citizen

2. Devotion to God Almighty

3. At least 27 years old

4. Physical and mental health

5. Graduated with a Bachelor of Laws degree and two notary degrees, with a Master's degree in Notary (M. Kn) 
6. Have undergone an internship or have clearly worked as a Notary employee for 12 consecutive months at the Notary's Office on their own initiative or on the recommendation of the Notary Organization after graduating Strata Two Notary (M. Kn)

7. Not a status as a civil servant, state official, advocate or not holding another position which by law is prohibited from being concurrently appointed as a notary public.

To become a notary you must now pass a strict selection. On its official website, the Directorate General of General Law Administration of the Ministry of Law and Human Rights announced since early January 2018 about the mechanism for notary appointment as a new requirement to become a notary public. In addition to the Notary Ethics Code Test (UKEN), the Extraordinary Member (ALB) Tests as a requirement to take Notary Ethics Code Test, as well as the Notary Master's graduation thesis tests must be passed to become a notary public.

\section{Review of Literature}

\subsection{Public Official}

The term "Public Official" is a translation of the term Openbare Amtbtenaren contained in Article 1 of the Notary Position Regulation and Article 1868 of the Civil Code.

According to the legal dictionary, one of the meanings of Ambtenaren is the Official. Likewise, Openbare Ambtenaren is "an official who has a duty related to the interests of the community, so that Openbare Ambtenaren is defined as an Officer assigned with the task of making authentic deeds that serve the interests of the community, and such qualifications are given to the Notary".

A general official is a person appointed by an authorized agency with the task of serving the general public in certain fields of activity. Certain activities here include making a deed.

Public Official is an Officer who is appointed and dismissed by public authority (the state is represented by the Government), and is given the authority and obligation to serve the public in certain matters, therefore he also carries out the authority of the Government. This is what distinguishes a Notary from other Officials in the community, because although other Officials are also appointed by the Government or obtained permission from the Government, the nature of their appointment is merely the granting of a license or license to carry out a position, not directly bearing the position of the State. For example, Advocates, General Physicians, Public Accountants and others. They do free work, do not have the nature of a Public Official, because the work he does is not sourced from Government authority. They are private people who are only bound by the rules regarding position, and then they are free to do their profession. They may choose themselves where they will work, not bound by leave rules and administrative regulations that are closely related to their work.

\subsection{Notary}

According to the Indonesian Dictionary, "Notary means the person who is authorized by the government based on the appointment (in this case the Department of Law and Human Rights) to authorize and witness various agreements, wills, deeds, etc."

Definition of Notary according to Article 1 number 1 of Law Number 2 of 2014 concerning Amendment to Law Number 30 of 2004 concerning Notary Position determines "Notary Public is the authorized official to make an authentic deed and other authorities as referred to in this law". While in the explanation of the Law of notary position states that: "Notary is a 
public official authorized to make an authentic deed as long as the making of a certain authentic deed is not specific to other public officials".

The understanding given by the Law of notary position refers to the duties and authority of the notary. This means that the Notary has the duty as a public official and has the authority to make an authentic deed and other authorities regulated by the Law of notary position.

\section{Research Method}

This type of research used in this study is normative legal research. Normative legal research is also called doctrinal law research because this research is carried out by analyzing written law from library materials or secondary data better known as names and reference materials in the field of law or reference material in the field of law.

\section{Discussion}

Since early January 2018 the Ministry of Law and Human Rights announced a new mechanism for the appointment of a notary public as a condition to become a notary public. Not only the Notary Ethics Code Test (UKEN), prospective notaries must take preExtraordinary Member (ALB) tests as a prerequisite for taking Notary Ethics Code Test, and the notary master's thesis tests must be passed to become a notary public. This rule is based on the Minister of Law and Human Rights Regulation Number 62 Year 2016 concerning Amendments to the Minister of Law and Human Rights Regulation Number 25 Year 2014 concerning Terms and Procedures for Appointment, Transfer, Dismissal, and Extension of Term of Office of Notary (Permenkumham 62/2016) and Minister of Law and Human Rights Regulation (Permenkumham) Number 25 of 2017 concerning the Notary Appointment Test. In the Minister of Law and Human Rights Regulation of 62/2016 it is stated that for the first time the requirements for the appointment tests in Article 2 paragraph 2 letter $\mathrm{j}$ that the completeness of supporting documents to be appointed as a notary includes a photocopy of the graduation mark of the notary appointment tests held by the Director General Law Administration which has been legalized.

The Minister of Law and Human Rights Regulation of 25/2017 regarding the Notary Appointment Test regulates the details of the notary appointment tests mechanism. The appointment test provisions take effect in March 2018. Notary candidates whose appointment documents are still in the Waiting List or Reserved Waiting Category and have not yet received formation in 2017 are required to take this appointment test. The appointment tests must be followed by prospective notaries who have just applied for an appointment from 2018 onwards. The initial appointment tests is held in April 2018 at a cost of Rp 1,000,000.

For the appointment test material, there will be a minimum of 10 materials, namely the institutional organization of the Ministry of Law and Human Rights; appointment of a Notary Public, the transfer of a Notary Public, the extension of the term of the Notary Public, the dismissal of the Notary, supervision, and guidance to the Notary Public; named and unnamed agreements; the establishment and amendment of the statutes of limited liability companies, foundations and associations; material guarantees and personal guarantees; fiduciary guarantee registration; civil and testamentary inheritance law; bankruptcy; legalization and waarmerking; attitude and behavior of a notary public.

The management of the Indonesian Notary Association Center (PP-INI) since 2017 has made a new regulation, namely every notary candidate who will take the Notary Ethics Code 
Test must take the Pre- Extraordinary Member tests first. The Pre-Extraordinary Member tests consists of multiple choice questions, essays and interviews with material about the organization of the management of the Indonesian Notary Association Center. For Notary Ethics Code Test material, aside from relating to the code of ethics, a lot of it comes from the Law of Notary Position. The management of the Indonesian Notary Association Center also issued a rule, Notary Ethics Code Test participants since 2018 must have completed their internship obligations for 24 consecutive months as a condition for joining Notary Ethics Code Test. The appointment tests will be the final test for notary candidates who can be followed with the condition that they have passed Notary Ethics Code Test. In addition, notary candidates need to ensure other requirements set by the management of the Indonesian Notary Association Center and the Ministry of Law and Human Rights.

Based on the above provisions, to take part in the Notary Ethics Code Test and appointment of a notary must be an Extraordinary Member of the Indonesian Notary Association. What is meant by Extraordinary Members of the Indonesian Notary Association is that every person who has graduated from notary education is registered as a member of an association. In the provision of Article 4 Paragraph (1) Letter b Amendments to the Domestic Statutes of the Indonesian Notary Association which are held in Balik Papan City in 2017, extraordinary members must pass the extraordinary member registration tests organized by the association with the Articles of Association, by-laws, and Association Rules.

Based on interviews conducted by the Writer team with the Chairperson of the Regional Committee of the Indonesian Notary Association, the Extraordinary Member Tests for the Indonesian Notary Association is only a formality aimed at introducing this Statutes and bylaws (AD / ART) of Indonesian Notary Association, Organizational Regulations and Management Structure to these prospective members who take the external member tests ordinary. Because there is a formality, no tests participants do not pass as long as the tests follow the entire tests material. Therefore the Writers' team considers that the extraordinary member tests of Indonesian Notary Association are more effective when they are turned into a seminar or training course because the basic objective is only to introduce the organization.

The Indonesian Notary Association is the only Notary Organization regulated in Law Number 30 of 2004 concerning Notary Position Article 82 and 83, then amended in Law Number 2 of 2014 concerning Amendment to Law Number Notary Article I 41 reads as follows:

1. Notary is assembled in one organization Notary Organization;

2. Notary Organization container as referred to in paragraph (1) is the Indonesian Notary Association;

3. Notary Organization as referred to in paragraph (1) is the only container of the profession of a free and independent notary profession formed with the intent and purpose of improving the quality of the Notary profession;

4. Provisions regarding the objectives, duties, authority, work procedures and organizational structure are stipulated in the Statutes and Bylaws of the Notary Organization;

5. Provisions regarding the stipulation, guidance and supervision of a Notary Organization shall be governed by a Ministerial Regulation.

As the only Organization for Notaries governed by the Law of Notary Position, of course the Indonesian Notary Association has a fairly long history, starting from the landing of the first Notary in Indonesia named Melchior Kerchem who was a Dutch national who 
precisely landed in Jakarta and was followed by the Another Dutch Indies Notary who later formed the Dutch Indies Notary Society.

Based on Boederschap van Candidaat-Notarissen in Nederlanden zijne Kolonien and Broederschap der Notarissen in the Netherlands, recognized as Legal Entity (rechtspersoon) with Besluit Gouvernements on Government date. Sept. 05. 1908 No.9. Article 1653 Civil Code divides the legal entity into 3 , one of which is a legal entity recognized by the Government/public authority, for testsple associations, churches and religious organizations and the Indonesian Notary Association is an association.

After Indonesian Independence, the Indonesian Notary, represented by its chairman, Notary Eliza Pondang, submitted a written request containing a change in the articles of association of the organization to the Indonesian government, at that time the Ministry of Justice of the Republic of Indonesia. After being accepted and the amendment to the articles of association declared valid and announced in Supplement to the State Gazette of Indonesia Number 19 dated March 6, 1959, the name of the association changed to Indonesian Notary Association.

Initially the purpose of Indonesian Notary Association was as a place for meetings and friendship between the Notaries who are members so that they can exchange ideas and chat with each other. Where is increasingly growing so that it has more functions such as in terms of supervision, or as a forum for the dissemination of information about the Notary by means of seminars and meetings that can build a stronger bond for the Notaries who gather there.

The code of ethics itself is a moral code determined by the Indonesian Association of Notaries that applies and must be obeyed by each and all members of the association and all those who carry out their duties as Notaries, including Temporary Notary Officials, Substitute Notaries when carrying out their positions. Oversight according to Article 7 Amendment to the Notary Code of Ethics Extraordinary Congress of the Indonesian Notary Association of Banten, May 29-30, 2015 is carried out by the Regional Honorary Council at the Regency / City level, by the Regional Honorary Council at the provincial level and the Central Honorary Council at the national level. The Notary Position of the supervisory duty is carried out by the Minister in which the Minister forms a Supervisory Board of 9 (nine) persons consisting of elements of:

1. Government of 3 (three) people;

2. Notary Organization of 3 (three) people; and

3. Experts or academics of 3 (three) people

It can be seen that with the existence of an honorary council in the area of the Indonesian Notary Association code of ethics, it is sufficient to pay attention to the issue of oversight of the office of the notary public. If you talk about the development of the Indonesian Notary Association, it is of course necessary to talk about the development of the Notary itself. Indonesia already has legislation in the field of notarial, namely "Notary Position Regulations" (Notary Reglement - Stbl. 1860-3), as a substitute for "Instructive voor notarissen in Indonesia" (Stbl. 1822-11).

The government is of the opinion that every judicial process that requires a notary tests by law enforcement officials must go through the approval of the Regional Supervisory Council (MPD) related to the deed (notary protocol) it makes. However, the notary because of his position has the right of renegade (verschoningrecht), the obligation of renegade (verschoningsplicht), and the obligation to provide information on the deed he made.

The specialty is regulated in Article 1909 paragraph (3) of the Civil Code and Article 322 of the Criminal Code. Therefore, each notary is required to keep the contents of the deed 
and information obtained in making the notarial deed, unless ordered by law. The position of the notary is based on the trust between the notary and the party using his services. Therefore, he can only give, show, or notify the contents of the deed, grosse deed, minuta deed, copy of the deed / quote deed to people who are directly interested or the parties mentioned in the deed, heirs.

In Article 66 paragraph (1) of the Notary Position Law governing the Regional Supervisory Council consists of 3 elements of government, 3 notary organizations, and 3 academics whose function is to oversee the implementation of the code of ethics of the notary public whose authority to receive reports and to hold hearings related to alleged violations of the notary public code of ethics. So the position of the Supervisory Board as an appraiser is whether a request submitted by a person or an investigator, public prosecutor, judge to take minuta deed or summon a notary can be approved or not.

Article 66 paragraph (1) states, For the benefit of investigators, public prosecutors, or judges with the approval of the Regional Supervisory Council authorized:

a) Take a photocopy of the Minuta of Deed and / or documents attached to the Minuta of Deed or Notary Protocol in the safekeeping of a Notary; and

b) Call the Notary to attend the tests relating to the deed he made or the Notary Protocol which is in the Notary's depository.

Therefore, to take a photocopy of the Minuta of the deed or the documents attached to the Minuta of the deed and summon a notary for tests purposes related to the deed he made, it must be approved by the Regional Supervisory Council. Article 66 of the Notary Position Law is stipulated more technically in Permenkumham Number M.03.HT.03.10 of 2007 concerning Terms and Procedures for Taking the Minuta of Deed and or Letters Put on the Minuta of Deed. The Permenkumham also regulates the procedure for summoning a notary as regulated in Chapter IV, Articles 14-18. On that basis, the government concluded that Regional Supervisory Council approval was needed to maintain a balance between the denial obligations held by the notary and the law enforcement process. This is to protect the notary in carrying out his duties.

In general, the requirements to become a notary candidate are a graduate of law and master of notary who are reliable and have good mental maturity, so that the decisions made are good and quality decisions. Then not having a criminal record is one way to gain public trust. There is a concern that if someone has committed a crime then in the future he will not hesitate to repeat it again. Although there is no guarantee that those who are clean from criminal records will be forever clean, but this requirement will filter out bad candidates. Then a notary must have good legal knowledge. This is because the notary is the representative of the state in making an authentic legal deed and educating the general public regarding issues of making, procuring, and other matters surrounding the deed.

Based on the provisions of Article 3 of Law Number 30 of 2004 jo. Law Number 2 of 2014 concerning Notary Position, the requirements to become a notary public are as follows:

1. Indonesian Citizen;

2. Devotion to God Almighty;

3. At least 27 (twenty seven) years old;

4. Physical and mental health;

5. Certified bachelor of law and master of notary;

6. Has undergone an internship or has clearly worked as a Notary employee for a minimum of 24 (twenty four) consecutive months at the Notary's Office on his own initiative or on the recommendation of the Notary Organization after graduating the notary strata two; 
7. Not a status as a civil servant, state position, advocate, or not holding another position which by law is prohibited from being concurrently appointed as a Notary Public.

8. Never been sentenced to imprisonment based on a court decision that has obtained permanent legal force for committing an offense threatened with imprisonment of 5 years or more.

Based on the Announcement of the Directorate General of General Law Administration of the Ministry of Law and Human Rights, since the beginning of January 2018 set the mechanism for the appointment of the Notary Public as a new condition to become a Notary. The requirements in question are completing the Notary Code of Ethics Tests, preExtraordinary Membership tests as a condition for taking Notary Code of Ethics Tests, and the Notary Appointment test.

This mechanism is based on the Minister of Law and Human Rights Regulation (Permenkumham) Number 62 of 2016 concerning Amendments to the Minister of Law and Human Rights Regulation Number 25 of 2014 concerning Terms and Procedures for Appointment, Transfer, Dismissal, and Extension of Term of Office of Notary Public (Permenkumham 62 / 2016) and Minister of Law and Human Rights Regulation No. 25 of 2017 concerning the Notary Appointment Test.

In addition to the tests other than those mentioned above, prospective notaries need to confirm other requirements set by Indonesian Notary Association Center and the Ministry of Law and Human Rights. Like a two-year apprenticeship, each notary candidate must collect 30 points as a condition of taking Notary Code of Ethics Tests. You do this by attending seminars held by Indonesian Notary Association. Central level seminars will get 6 (six) points, for regional level seminars will get 4 (four) points, and for regional level seminars will get 2 (two) points. The conditions for apprenticeship offices have been added in Minister of Law and Human Rights Regulation 62/2016. The internship must be carried out in a notary office that has a minimum service period of 5 (five) years and has issued at least 100 (one hundred) deeds. This requirement is also found in Minister of Law and Human Rights Regulation 25/2017 with the addition that in the apprenticeship program at the notary's office the prospective notary must have participated and his name stated at least in 20 deeds.

Minister of Law and Human Rights Regulation 62/2016 also requires that a request for appointment of a notary must attach a certificate of spiritual health from a psychiatrist or a specialist in a hospital's psychiatry stating that the applicant has good spiritual health conditions that are still valid (no later than one year from the date the certificate was issued). These requirements were made not to complicate notary candidates, but to better prepare prospective notaries to be ready to become public officials, because in practice in society people will face problems that are not in college

Based on the results of an interview with the Chairman of the Medan City Regional Board of Indonesian Notary Association, Dr. Ferry Limbong., SH., M. Kn, this extraordinary member tests is one of the requirements to take Notary Code of Ethics Tests. To become a notary, pass or not is determined through the notary appointment tests. However, in general, prospective notaries who have taken the tests of this extraordinary member will find it easier to face the Notary Code of Ethics Tests and notary appointment tests. That is because prospective notaries who have taken the tests of this extraordinary member will better understand the ins and outs of the notary world. 


\section{Conclusion}

The extraordinary Members Tests of Indonesian Notary Association is only a formality aimed at introducing Statutes and bylaws of Indonesian Notary Association, Organizational Regulations and Composition of Indonesian Notary Association Management to prospective members who take the tests of extraordinary members. Because there is a formality, no tests participants do not pass as long as the tests follow the entire tests material. Therefore the Writers' team considers that the extraordinary member tests are more effective when they are turned into a seminar or training course because the basic objective is only to introduce the organization.

In addition to meeting general requirements in the Law of Notary Position, currently a prospective notary must take the Extraordinary Members Tests of Indonesian Notary Association, the Notary Ethics test and the Notary Appointment test. This new provision is based on the Minister of Law and Human Rights Regulation Number 62 of 2016 concerning Amendments to the Minister of Law and Human Rights Regulation Number 25 of 2014 concerning Terms and Procedures for Appointment, Displacement, Dismissal and Extension of Term of Office of Notary.

\section{References}

Adjie, Habib. 2008. Hukum Notaris Indonesia (Tafsir Tematik terhadap UU No 30 Tahun 2004 tentang Jabatan Notaris). Bandung: Refika Aditama.

Anshori, Abdul Ghofur. 2009. Lembaga Kenotariatan Indonesia Perspektif Hukum dan Etika. Yogyakarta :UII Press.

ASH, Miliki Hak Ingkar, Notaris Wajib Rahasikan Isi Akta, Pasal 66 Ayat (1) UU Jabatan Notaris Dinilai Tidak Bertentangan Dengan Undang-Undang Dasar 1945, https://www.hukumonline.com/berita/baca/lt4ff5751b7abce/miliki-hak-ingkar--notariswajib-rahasiakan-isi-akta/, diakses pada 5 Januari 2019 pukul 23.35 WIB

Budiono, Herlien. 2007. Notaris dan Kode Etiknya. Medan: Upgrading dan Refreshing Course Nasional Ikatan Notaris Indonesia.

Devi, Notaris sebagai Pejabat Umum, sebagaimana dimuat dalam http://sekilasnotaris.blogspot.co.id/2009/04/notaris-sebagai-pejabat-umum.html diakses pada tanggal 21 Februari 2018 pukul 23.07 WIB.

G.H.S. Lumban Tobing. 1992. Peraturan Jabatan Notaris. Jakarta: Erlangga.

Johny Ibrahim. 2011. Teori \& Metodologi Penelitian Hukum Normatif. Malang : Bayu Media Publishing.

Krisdianto R. Maradesa, Kewenangan Serta Tanggung Jawab Hukum Atas Pembuatan Akta Otentik Oleh Notaris Berdasarkan Undang-Undang Tentang Jabatan Notaris, Jurnal Lex Privatum, Vol.II/No. 3/Ags-Okt/2014, Manado: Universitas Sam Ratulangi

Koran Sulindo. Ada Syarat Baru untuk Jadi Notaris. Sebagaimana dimuat dalam http://koransulindo.com/ada-syarat-baru-untuk-jadi-notaris/ diakses pada 21 Februari 2018 pukul 23.35 WIB.

Ling Fransiska dan Endang Pandamsari, Tinjauan Yuridis Terhadap Tanggung Jawab Notaris Dalam Mebuat Ppjb Nomor 32 (Studi Putusan Nomor ; 28/Pdt.G/2015/Pn.Bgr), Jurnal Hukum Adigama, Jakarta: Universitas Tarumanagara 
Mansyur, Andi Ahmad Suhar. 2013. Analisis Yuridis Normatif terhadap Pemalsuan Akta Otentik yang Dilakukan oleh Notaris. Jurnal Karya Ilmiah, Fakultas Hukum Universitas Brawijaya.

Marzuki, Peter Mahmud. 2010. Penelitian Hukum. Jakarta: Kencana.

Nasution, S. 2007. Metode Research (Penelitian Ilmiah). Bumi Aksara. Jakarta

Notodisoerjo, R. Soegondo. 1993. Hukum Notariat Di Indonesia: Suatu Penjelasan. Jakarta: Raja Grafindo Persada.

Norman Edwin Elnizar, Jalan Panjang dan Berliku, Kini Menjadi Notaris Harus Lulus 4 Ujian Khusus Seleksi diperketat untuk meningkatkan kualitas notaris selaku pejabat umum perpanjangan tangan Pemerintah, https://www.hukumonline.com/berita/baca/lt5a5ca66054da6/jalan-panjang-dan-berliku-kini-menjadi-notaris-harus-lulus-4-ujian-khusus/ diakses pada 5 Januari 2019 pukul 23.35 WIB

Oloan, N., (2016), Praktek Pembuat Akta Tanah oleh Camat dalam Kedudukan dan Fungsinya Selaku PPAT Sementara di Kota Padangsidimpuan, Jurnal Pendidikan Ilmuilmu Sosial, 8 (2): 123-127.

Peraturan Menteri Hukum dan HAM RI No. 25 Tahun 2017 tentang Ujian Pengangkatan Notaris.

Rahayu, Ridha Eka. Profesi Notaris. Sebagaimana dimuat dalam https://ridhamujahidahulumuddin.wordpress.com/2017/05/27/makalah-profesi-notaris/ diakses pada 21 Februari 2018 pukul 23.15 WIB.

Sejarah Notaris, https://riz4ldee.wordpress.com/2009/03/04/sejarah-notaris/, diakses pada 5 Januari 2019 pukul 23.35 WIB

Stephanie dan Endang Pandamdari, Peranan Ikatan Notaris Indonesia (Ini) Terhadap Pengawasan Notaris Dalam Pelaksanaan Tugas Jabatan Notaris Di Provinsi Dki Jakarta, Jurnal Hukum Adigama, Jakarta: Universitas Tarumanagara

Soekanto, Soerjono. 1998. Metodologi Research Yogyakarta: Andi Offset.

Soekanto, Soerjono \& Sri Mamudji, 1995. Penelitian Hukum Normatif: Suatu Tinjauan Singkat. Jakarta: PT Raja Grafindo Persada.

Tim Penyusun Kamus Pusat Pembinaan dan Pengembangan Bahasa. 1990. Kamus Besar Bahasa Indonesia. Cetakan ke-3. Jakarta: Balai Pustaka.

Yanti Jacline Jennier Tobing, Pengawasan Majelis Pengawas Notaris Dalam Pelanggaran Jabatan dan Kode Etik Notaris, Jurnal Media Hukum, 2010 